\title{
COVID-19 Pandemic and Surge Capacity
}

\section{COVID-19 Pandemisi ve Taşma Kapasitesi}

\author{
(D) Miraç Nevzat KARAKOÇ1, id Özcan ERDOĞAN²
}

${ }^{1}$ Çanakkale Special Provincial Administration, Investment and Construction Directorate, Çanakkale, Turkey

2Bezmialem Vakıf University Faculty of Medicine, Department of Disaster Management, İstanbul, Turkey

\section{ABSTRACT}

Disasters and pandemics experienced in recent years have shown the importance of emergency preparedness. Effectively responding to events leading to a large influx of patients that disrupt daily operations requires increased capacity. Not much resources may be available to recover losses in the current healthcare system. Therefore, plans should be made for the overflow capacity to accommodate a large number of patients before the disaster. In the face of a complex emergency epidemic, it is very important to identify and verify resources from the beginning of the outbreak in order to scale and use efficiently. It is necessary to make alternative plans and produce solutions against the worst possible scenario. In Coronavirus disease-2019 pandemics, as in all disasters and pandemics, trying to reduce the number of cases for overflow capacity, establishing alternative health facilities, minimizing the resource consumption of patients and increasing the bed capacity should be basic strategies. The need for excess resources arising in the overflow capacity experienced in a pandemic should be evaluated correctly and planning should be done accordingly. Therefore, it is necessary to create alternative areas. Projecting the underground car parks of the hospitals as underground hospitals in case of a naturerelated disaster, and evaluating other closed areas within this scope; Again, the parks and reserve areas in the cities should be planned for the establishment of field hospitals against different scenarios against each natural disaster situation. With these plans, physical area demands that will occur in response to the overflow capacity can be supplied.

Keywords: COVID-19, pandemic, surge capacity, underground hospital
ÖZ

Son yıllarda yaşanan afetler ve pandemiler, acil durum hazırlığının önemini göstermiştir. Günlük operasyonları bozan büyük bir hasta akınına yol açan olaylara etkili bir şekilde yanıt verebilmek, kapasite artışı gerektirir. Mevcut sağlık sisteminde kayıpları gidermek için çok fazla kaynak bulunmayabilir. Bu nedenle afet öncesi, çok sayıda hastayı barındıracak taşma kapasitesi için planlar yapılmalıdır. Karmaşık bir acil salgın durumu karşısında kaynakların doğru ölçeklendirilmesi ve verimli bir biçimde kullanılabilmesi için salgının başlangıcından itibaren tespit edilmesi ve doğrulanması çok önemlidir. Ortaya çıkabilecek en kötü senaryoya karşı alternatif planlamalar yapmak ve çözüm üretmek gerekmektedir. Coronavirüs hastalığı-2019 pandemisinde de tüm afetlerde ve pandemilerdeki gibi taşma kapasitesine yönelik olarak olgu sayısını azaltmaya çalışmak, alternatif sağlık tesisleri kurmak, hastaların kaynak tüketimini en aza indirmek ve yatak kapasitesini arttırmak temel stratejiler olmalıdır. Bir pandemide yaşanan taşma kapasitesinde ortaya çıkan aşırı kaynak ihtiyacı doğru değerlendirilmelidir ve planlamalar buna göre yapılmalıdır. Bu sebeple alternatif alanlar yaratmak gerekmektedir. Hastanelerin yeraltında bulunan otoparklarının bir doğa kaynaklı afet durumunda yeraltı hastanesi olarak projelendirilmesi, diğer kapalı alanların da bu kapsamda değerlendirilmesi; yine şehirlerde yer alan park ve rezerv alanlarının da her bir afet durumuna karşı sahra hastaneleri kurulumu için planlanması gerekmektedir. Bu planlamalar ile taşma kapasitesine karşılık ortaya çıacak fiziksel alan talepleri karşılanabilecektir.

Anahtar Sözcükler: COVİD-19, pandemi, taşma kapasitesi, yeraltı hastanesi

Address for Correspondence: Miraç Nevzat KARAKOÇ, Çanakkale Special Provincial Administration, Investment and Construction Directorate, Çanakkale, Turkey

E-mail: mnkarakoc@hotmail.com ORCID ID: orcid.org/0000-0001-7105-0858 


\section{Introduction}

Disasters cause physical, economic or social losses by leading to many damages in the places where they occur. As a result of disasters, for hospitals and the general public, when an event that causes a large number of acute injuries and/or patients occurs, it is important to evaluate and plan the number of available beds according to the need. The ability of a hospital to adapt to the sudden influx of patients who need to be hospitalized due to disasters or any other reason is called the 'surge capacity of hospitals' (1). Plans for surge capacity should allow the activation of more than one capacity from the routine level to the highest level of the healthcare facility. Therefore, before the disaster, plans for the surge capacity to accommodate a large number of patients should be made for each level.

Correct assessment of the surge capacity is also important when faced with outbreaks of infectious diseases that occur naturally or as a result of bioterrorism (2). In fact, surge capacity is not a new concept, as auxiliary hospitals were used in past smallpox and pandemic influenza events (3). Infectious disease outbreaks such as Severe Acute Respiratory Syndrome (SARS) or pandemic bird flu can potentially be considered as other examples of large-scale events (4).

\section{Hospital Surge Capacity in Disasters}

Outbreaks of infectious diseases in recent years have demonstrated the importance of emergency preparedness for major events affecting many people. To be able to respond effectively to events that generate a large influx of patients disrupting daily operations requires an increase in capacity. The main components of the surge capacity can be considered as "personnel, materials, structures and systems". In addition, a critical component of responding to large-scale disasters is the surge stress capacity (4). Effective health emergency preparedness requires planning of large-scale events that affect many people.

Emergencies and disasters can cause disorganization in social and organizational activities. On the other hand, effective management of these destructive and damaging events depends on anticipating the problems associated with these events and making plans to effectively respond to them. The first and foremost demand of people in these events is their health and well-being; Health systems should therefore play a key role in reducing deaths and injuries. All preparations and planning made by the hospital to cope with disasters constitute an important part of the health system programs used to reduce the loss and disability that may occur (5).

Hospital surge capacity is defined as the ability to provide acute care to both critical and non-critical mass events at the same time, and is an indicator of the ability to provide emergency care in the event of a disaster. The best international practice models for mass patient care state that the number of available operating rooms and the ability to take simple X-rays are the measures of the capacity to care for both critical and non-critical patients. The number of intensive care unit (ICU) beds is also one of the physical indicators of the capacity to provide care to critically hospitalized patients, but there is no internationally accepted criterion for this (6).

Many studies consider the ability to increase capacity in addition to using available resources to manage the sudden flow of injured people or patients with respect to surge capacity. Hospital surge capacity has 3 main components:

\section{Human resources,}

2. Specific/non-specific equipment,

\section{Physical area.}

The hospital surge capacity program is dynamic and needs to be constantly reviewed and updated when necessary. Excessive surge capacity programs should be developed and implemented on the basis of assessment and risk analysis. Therefore, before developing this program, risks or hazards threatening hospitals must be identified and hospital's security gap must be evaluated (5).

Surge capacity is an essential element of hospital disaster management plans and organizational endurance plans. However, the lack of a coherent and integrated approach has consequences that can leave some health facilities and surrounding communities vulnerable. Therefore, fluctuations that may occur in the scenarios created in hospital disaster plans drills may create a problem for hospital managers. For this reason, there is a need for fluctuation capacity protocols based on comprehensive plans that can be implemented in emergency situations (7).

Hospitals may not have sufficient space to accommodate patients in need of emergency medical care. Managers can take action for the sudden provision of additional medical services to meet the increased demand in response to surge capacity. Operational strategies that increase the surge capacity should be studied and how these can be implemented in the most effective way according to the characteristics of the hospitals should be determined (8).

\section{Components of Surge Capacity}

Surge capacity is defined as a significant increase in resource demand compared to basic demand. Regarding healthcare, surge represents a significant increase in demand for medical or public health resources. In addition to mass influx (volume ratio), surge also consists of event (type, scale and duration) and resource demand (consumption and deterioration) components. Figure 1 shows the surge response capacity as a function of surge capacity (resource availability) and surge (resource demand) components (9).

For natural disaster events, the components of the surge capacity are only defined broadly and many subcomponents are not defined. Also, the relative effect of the various components under different event scenarios is largely unknown. Nevertheless, surge response capacity, which is a new concept, can be expressed as a function of surge capacity and surge characteristics (9). 


\section{Use of Capacity in Hospitals}

To interpret the relationship between the concepts of daily patient capacity and surge capacity; both concepts are similar in terms of struggling a large increase in both medical and public health resource demand and questioning system capacity. However, surge capacity, which is a term used for disaster events, is larger in scale, more complex, and has nonlinear multicomponent interactions incremental with capacity, compared to the simpler daily patient capacity (9).

In an event with a large number of patients, hospital surge capacity is the core of the hospital medical intervention and is an integral part of the total medical capacity of the affected community (10). Hospitals are the first structures that come to mind in health care, but expanded care facilities, community health centers, laboratories and public health departments also constitute the structural component of the surge capacity (4).

Operational decisions involved in managing surge capacity can be evaluated within a broader conceptual framework consisting of four stages: preparedness, response, recovery and mitigation (Figure 2).

Hospitals establish the hospital capacity during the preparation phase and determine the resources that can be used in emergency situations. During the response phase, the hospital responds to the emergency and controls its negative effects. During the recovery phase, the hospital continues its normal operations. In the mitigation phase, the hospital takes measures to reduce the severity and impact of an emergency on its operations (11).

\section{Pandemic}

Pandemics are disease outbreaks that are widespread, mostly as a result of the spread of infection from person to person and are declared by the World Health Organization (WHO) (12). The impact of the pandemic at the community level varies depending on the contagiousness of the microorganism, its virulence, the immune status of the individuals in the society, the contact among the individuals and transportation characteristics among societies, the presence of risk factors, the health services provided

Taşma Yanıt Kapasitesi $=$ Planlama

Azami Kullanılabilir Kaynaklar

Kaynak Talebi

Taşma Kapasitesi

$=$ Planlama *

Taşma

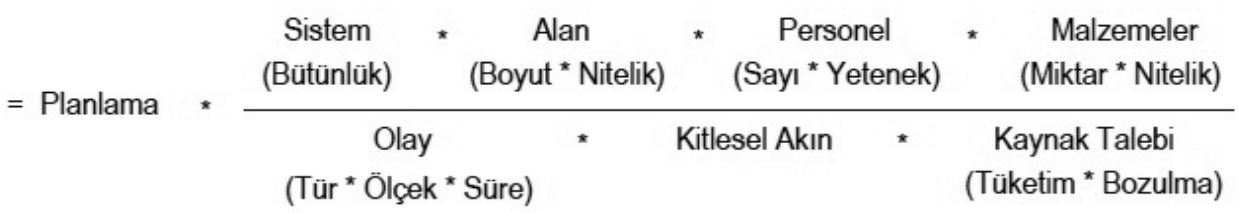

Figure 1. The fluctuation capacity of the surge response capacity and its functional relationship with the fluctuation

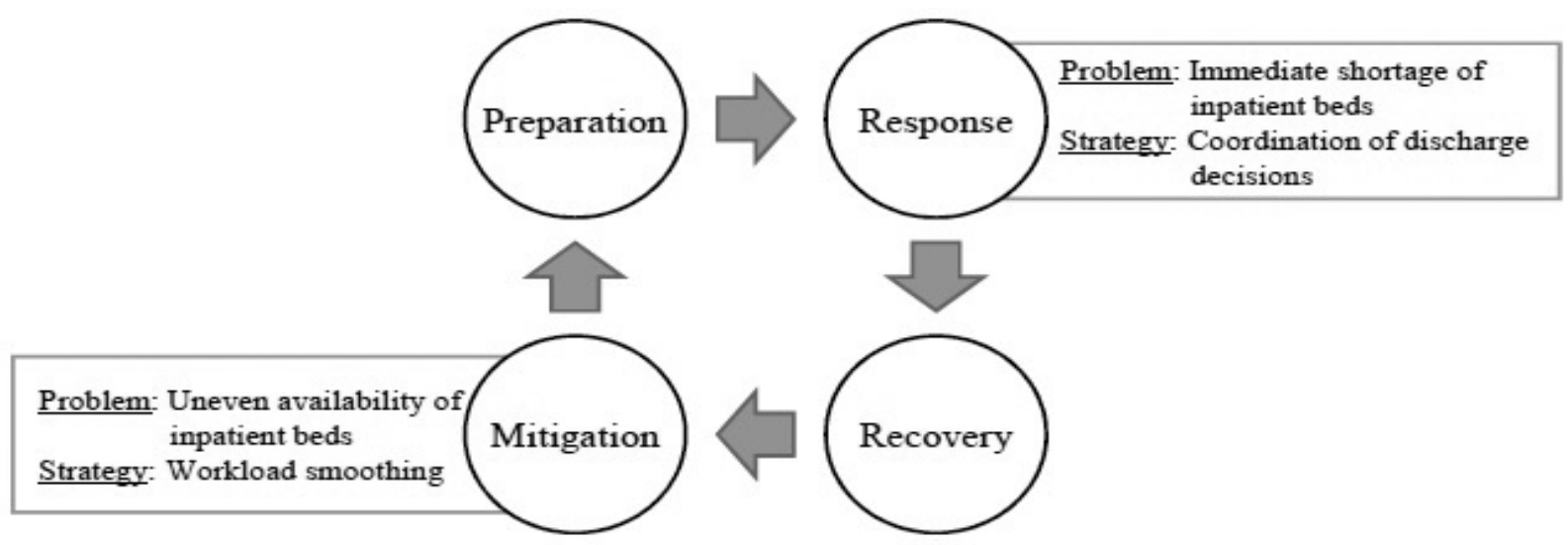

Figure 2. Problems-strategies in the framework of emergency response (4) 
and the climate. Throughout human history, many important pandemics such as smallpox, cholera, plague, dengue, AIDS, influenza, SARS have been recorded (13).

\section{COVID-19}

The first coronavirus case was reported as a common cold in 1960. In a study conducted in Canada in 2001, a flu-like disease was observed in approximately 500 patients. It was confirmed by polymerase chain reaction method that $17-18$ cases were infected by coronavirus during this pandemic. Corona was considered a simple non-fatal virus until 2002. In 2003, various reports were published with evidence that the coronavirus spread to many countries such as the United States of America, Hong Kong, Singapore, Thailand, Vietnam and Taiwan. In 2003, more than 1,000 cases of SARS were reported in coronavirus-infected patients who experienced the fatal syndrome (14).

The acute respiratory infection pandemic that we are currently experiencing, caused by COVID-19, occurred on December 12, 2019 in Wuhan, China, possibly caused by bats in a seafood market. Studies have suggested that the bat may be a potential reservoir of SARS-Coronavirus-2 (15). On January 7, 2020, it was announced that the causative virus was a new coronavirus (2019-nCoV) that was not previously detected in humans. Then, the name of the 2019-nCoV disease was accepted as COVID-19 (16). It is the seventh coronavirus causing disease in humans. The virus is named this way because of its crown-shaped (corona) protrusions (17).

\section{Surge Capacity in Pandemics}

Planning an unpredictable, effective, long-term and widespread health emergency is difficult, but imperative. It requires a "social integration" and a coordinated effort in which all public stakeholders collaborate (18). Significant assessments should be made when public health decisions are needed to be useful. For this purpose, a serious risk assessment should provide as much information as possible about an emerging outbreak to answer the following key questions.

- How fast do new cases occur?

- What types of diseases and complications are observed?

- Which groups of people (eg. age groups or groups at risk of serious consequences) will become severely ill and die?

- Is the microorganism sensitive to antimicrobial agents?

- How many people will get sick?

- How will it th affect the health sector, including factors such as healthcare use and impact on the health workforce?

Operationally, these questions will help guide decisions regarding vaccine production and strategy for its use, antimicrobial use, mobilization of health resources, school closures, and other social distancing strategies (19).
In the occurrence of a complex emergency pandemic, it is very important to detect and verify the outbreak from the beginning so that resources can be scaled correctly and used efficiently. In addition to all factors, patient surveillance in a hospital and communication infrastructure against risks are vital for controlling and struggling epidemics (7). It is recommended that hospital management move to a team that can provide clinical surge capacity and deploy quickly during the outbreak (20).

In pandemics, the primary care system is always needed to be sensitive and high-capacity. Pre-hospital screening and prehospital and post-hospital care are crucial to patient survival. Since there will be an intense increase in patients in the event of an epidemic, it is unthinkable for the emergency department to provide healthcare services to all patients or for hospitals to accept patients and provide care without evaluating the status of alternative facilities (21).

Epidemic and pandemic planning offers the opportunity to integrate the primary, secondary and tertiary levels by using the rules of public health and the public administrative resource infrastructure in increasing the health capacity in primary care and in the care service. With this planning, patients are helped to receive health care services at home with primary care under the supervision of a doctor (21).

It is difficult to respond to the need for healthcare services that will arise with the occurrence of excessive capacity increase in infectious disease epidemics and similar emergency health situations. There may be problems in meeting the need for extra bed (2).

Healthcare professionals have a responsibility to treat as many patients as possible to survive in a disaster or emergency. Responsible personnel evaluate patients under limited conditions and resources in the field of triage and rank them for treatment priority. Correct triage management is achieved by ensuring medical success with scarce resources. Triage is valid for all disasters regardless of their size (2).

In the event of a pandemic, home care may not be provided for pandemic influenza patients with complex respiratory management needs. Instead, some patients who need hospitallevel care but do not need 24-hour supervision are provided care at home. By providing home care for these patients, hospital beds can be used for severe pandemic patients (22).

\section{COVID-19 Surge Capacity Strategies}

When designing health systems, the study is done according to the average patient load, not the number of patients that will arise in the presence of the epidemic. With the occurrence of COVID-19, it is seen that countries with a high number of patients are faced with a patient burden far above the capacity of health centers. For example, a study by Imperial College suggested an 8 to 30 -fold increase in health system capacities for the UK and the USA (23). 
The high rates of serious and critical cases in the development of the evolution of the epidemic in some countries have shown that the surge capacity must be increased rapidly in order to prevent the rapid depletion of medical supplies and the shortage of health personnel. It has been observed that the increase in cases has doubled or become more in three days in some countries. According to the largest cohort of COVID-19 patients, it has been observed that this disease is a mild disease that is symptomatic but does not require inpatient care in $40 \%$ of patients; a moderate disease that will require inpatient care in $40 \%$ of them; a disease requiring oxygen therapy or serious patient intervention in $15 \%$ of the patients; and a critical disease requiring mechanical ventilation in 5\% of cases (24). This shows that $55 \%$ of patients need inpatient treatment. Considering the number of cases here, the available hospitalization areas may not be sufficient for the number of patients that will arise as a result of the surge capacity. A 4-item strategy has been considered to increase capacity (25).

a. Trying to reduce the number of COVID-19 cases in order to increase capacity: Explaining the ways of protection against the virus to the society, directing non-emergency patients to alternative health centers instead of emergency services, urgently discharging patients who need to be discharged, and postponing all unnecessary health services.

b. Establishment of alternative health facilities: Foundation of alternative medical centers (underground hospitals, field hospitals, activation of non-used/closed hospitals, use of nursing homes as health centers). Using places that do not provide medical services as health centers (public spaces, hotels, dormitories).

c. Minimizing the resource consumption of admitted patients: Giving patients only the health care they need. Patients should not be admitted to the isolation room except when necessary.

d. Increasing bed capacity: Taking low-risk patients into nonused areas for regular health care provides more space for highrisk patients who need ICU. Any area that provides a room standard and isolated environment can be used.

The Monroe State Administrator of the United States, Adam Bello, and health officials, which has been most affected by the COVID-19 virus, explained the stages of the plan for the surge capacity as follows (26);

Stage one: Make existing beds available and delay any nonemergency surgery.

Stage two: Transform the busy or outpatient clinics of the hospital into areas that can provide patient care.

Stage three: Expand into unconventional physical spaces, transform spaces such as corridors into patient care rooms, double the number of non-COVID-19 patients in private rooms.

Stage four: Create a field hospital.

\section{Surge Capacity Strategies Against COVID-19 Pandemic in Turkey}

With the occurrence of the COVID-19 crisis, countries have taken some measures to reduce the effects of the emerging crises. Forty-six of the 214 world countries $(21.5 \%)$ announced at least 97 measures in response to the COVID-19 outbreak in the first periods of the pandemic (between February 1 and March 22, 2020). Thirteen countries (28.9\% of the countries in the region) in the Asia and Pacific region, where the epidemic originated, announced the measures they took against the crisis. Later, 11 countries in Europe and Central Asia (36.2\%), 11 countries in the American continents (24.4\%) and 1 country in Arab countries $(8.3 \%)$ explained the measures they took (Figure 3) (27).

The first COVID-19 case in Turkey was a patient who was detected to catch the virus as a result of a contact in Europe on March 11, 2020. In order to minimize the negative effects of the virus after the occurrence of the first case, the government of the Republic of Turkey started to work urgently for taking precautions with the guidance of the WHO and the Republic of Turkey Ministry of Health. The measures emerging as a result of these studies were put under a heading and published by the Ministry of Health (28);

\section{Precautions to be Taken in Blood Centers}

2. Measures to be Taken for Protection from COVID-19 in the Provinces where Seasonal Agricultural Workers will Go to Work

3. Measures to be Taken for Morgue and Burial Services

4. Precautions to be Taken at Airports

5. Recommendations for Security Control and Passport Officers at Airports

6. Precautions to be Taken in Accommodation Facilities

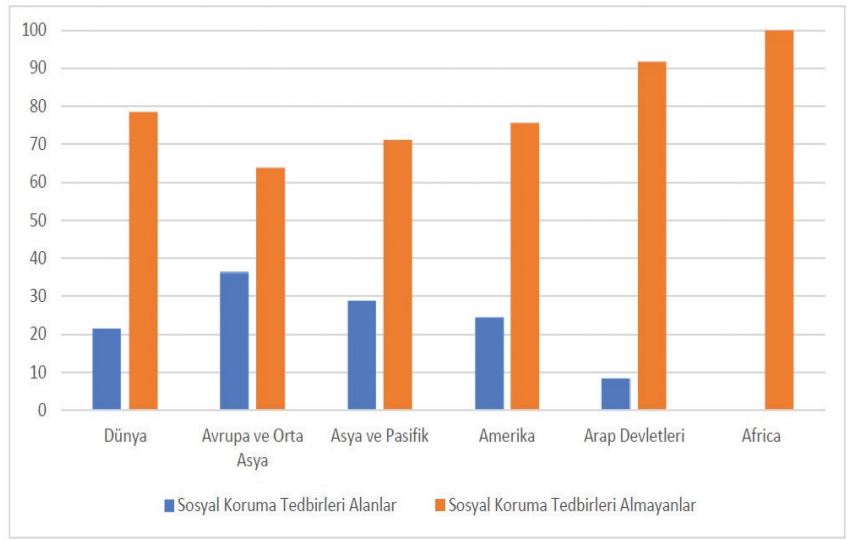

World Europe and Central Asia Asia and Pacific America Arab countries Africa

Those taking social protection measures

Those not taking social protection measures

Figure 3. Percentage of countries to take social measures according to regions in the world 
7. Cleaning Measures for Public Transportation Vehicles

8. Protection and Control Measures in Bank Branches

9. Measures to be Taken in Food Markets

10. Precautions to be Taken in Restaurants

11. Precautions to be Taken in Nursing Homes and Elderly Care Centers

12. Precautions to be Taken in Traditional and Complementary Medicine Units \& Centers and Beauty \& Medical Aesthetic Centers

13. Measures to be Taken in Penal Institutions of the Republic of Turkey Ministry of Justice.

Turkey has brought some rules for social measures in the context of determined struggle with COVID-19 pandemic;

- Airway transportation to 20 countries was stopped.

- A 14-day home quarantine obligation was imposed for citizens from abroad.

- Primary schools, high schools and universities were closed, and education activities were initiated on the internet from home.

- Administrative leave was given to pregnant women working in the public sector, those on breastfeeding leave, the disabled, those with chronic illnesses and personnel over 60 years of age until a second decision.

- A decision was made to work in turns for personnel in public sector.

- In order to raise the awareness of the public, public service announcements were started in all social media areas on the issues of virus protection and providing social distance.

- In all metropolitan cities (31 provinces) in the country, a curfew was imposed on weekends.

- The permissions of the soldiers in the barracks were stopped.

- Visits and transfers in penal institutions were suspended.

- Non-urgent trials and other judicial proceedings were postponed.

- Cultural and artistic activities were postponed.

- Mosques and masjids were closed to worship.

- Restrictions for going out were imposed first for citizens over the age of 65 years and then for those under the age of 20 years in Turkey.

- All scheduled national and international scientific activities, open and closed meetings, congresses, conferences, military exercises, paid military service calls were postponed.

- Activities where people come together, such as general assemblies and training activities, were postponed.
- Football, basketball, handball and volleyball competitions were postponed due to the COVID-19 outbreak until a new decision.

- The activities of places such as coffee houses, cafes, cinemas, theaters, concert halls, wedding halls, Turkish baths, sports halls, internet cafes, indoor children's playgrounds, condolence houses were temporarily suspended.

- Activities of entertainment places such as bars, casinos, and nightclubs, anf of museums and libraries were stopped.

- Production of protective equipment was increased in the public and private sector. Support was provided to many textile companies for the production of protective equipment. The sale and export of all protective equipment produced was prohibited.

- A local ventilator was designed and its production was started.

- Free masks were distributed to all citizens by the state.

- The number of laboratories for the detection of COVID-19 cases was increased to 36 within the country.

\section{In addition, in order to prevent surge capacity in hospitals;}

- At the hospital entrances, the pre-triage area was determined and the patients with suspected covid were identified.

- Non-urgent surgeries were stopped in order to minimize the density in health institutions and alleviate the burden on health personnel.

- All public and private hospitals were accepted as pandemic hospitals and started to serve free of charge for epidemic treatment.

- The number of hospital ICU beds was increased.

- Planning and preparations were made to transform normal patient rooms and operating rooms into ICU beds in case of need.

- In order to use the existing beds for COVID-19 infected patients, inpatients who did not have an emergency situation were discharged and followed up at their homes.

- When the symptoms of COVID-19 positive patients were improved, their treatment was planned and their quarantine processes were completed at their homes.

The COVID-19 pandemic has shown that the world may face an epidemic that will be devastating at any moment. As can be seen from the number of cases and deaths around the world, the health system in the world is not prepared for such big epidemic risks. Turkey has revealed a health care system that will be an example to the world in terms of the rates of cases and mortality, with the measures taken after the occurrence of the first case and strong infrastructure of the health system.

According to the COVID-19 Status Report published by the Ministry of Health on 30.06.2020, the total number of hospitalizations due to COVID-19 in Turkey is 105,416 (29). Currently, hospital capacities are sufficient; however, against 
future epidemic risks that may arise at any time, the construction of two pandemic hospitals with a capacity of 1000 beds has been started in the district of Sancaktepe in Istanbul and in the Atatürk Airport area, which is closed to use, in Yeşilköy district. While each room of the hospitals is prepared for a single person, each room can be converted into an ICU room if needed, and both will have a fully-fledged hospital infrastructure.

\section{Investigation of Surge Capacity in the COVID-19 Pandemic with SWOT Analysis Matrix}

By conducting a SWOT analysis of the surge capacity in the COVID-19 pandemic, the strengths, weaknesses, opportunities and threats to be encountered were evaluated.

\section{SWOT Analysis}

The SWOT analysis applied is shown in the table below (Table 1).

For strengths, the strongest part emerging in the pandemic is the database on viruses. Knowing the viruses that have been seen before, their sources and treatment methods have created an important source of information in the fight against COVID-19. Despite the speed of the virus spreading, the ability to instantly share scientific studies on treatment in various parts of the world with the technological infrastructure is another strength, even if they are not approved. It is very important to use the press and social media correctly in order to slow the spread of the virus and to raise the awareness of the society. The rapid adaptation of the society to the pandemic process is effective in reducing the rate of spread of the virus.

For weaknesses, first of all, we can accept that the components of the virus are unknown and there is no vaccine to be used in treatment and prevention, as they negatively affect the treatment process. This not only delays the application of treatment methods against the virus, but also negatively affects the process of finding a vaccine that will be effective against the virus. The late detection of the source of the virus is one of the most important weaknesses for this process, because it directly affects the treatment process. Insufficient number of patient beds during the treatment process may prevent patients to access treatment. It can prevent the treatment of patients who need to be kept under surveillance at the hospital. Another important weakness is the insufficient number of health personnel to take part in the pandemic. A small number of personnel working at a busy pace can negatively affect the treatment process, and may cause transmission by reducing the resistance of the personnel to the virus. Also, the insufficient stocking of the drugs used in the treatment process is another important weakness. In case of pandemic risks that may arise at any time, not having enough medicine stock may negatively affect the treatment process. One of the most important weaknesses that directly affect the spread of the virus is the insensitivity and misconsciousness of the society to protection methods against the virus.
For opportunities, it is important to obtain new data in order to take precaution in advance against new types of viruses that may emerge. Making new plans for increasing the number of healthcare personnel in the occurrence of the pandemic, designing alternative physical places for hospitalization, facilitating the supply of drugs to be used in the treatment process, and providing protection materials (such as respirator, mask, gloves) can be considered as important opportunities.

For threats, the lack of information about the virus is a major threat that delays the availability of the vaccine. The insufficient number of healthcare professionals involved in the treatment process is an important factor that negatively affects patient treatment. Insufficient treatment areas and patient beds are among the biggest threats to patients' access to treatment. Incomplete or incorrect stocking of drugs to be used in the treatment process will negatively affect the treatment. Failure to raise the awareness of the society correctly and in time poses a serious threat to the rapid spread of the disease.

\section{SWOT Matrix}

The SWOT Matrix was applied to make a decision by focusing on strategically important elements with the data obtained through SWOT analysis. The SWOT Matrix applied is shown in the table below (Table 2).

\section{Conclusion}

The occurrence of pandemics is not limited to the winter season, and unlike seasonal flu, they can occur at any time of the year. In addition, they are not limited to a specific time and place, unlike an epidemic. Planning and measures to be taken before the epidemic occurs determine the level of economic and social impacts of the epidemic. The course of a pandemic can be reduced by effective infection control measures. The first of these control methods is to be prepared. Rapidly increasing urbanization also increases the patient burden in the health system. In parallel with this increase, in addition to strengthening the health system, planning should be made against possible outbreaks. Experiences have shown that no matter how advanced the health systems and technology in the countries are, there may be an epidemic situation beyond predictions. At this point, the resistance of existing health systems and technology cannot be a savior. It is necessary to make alternative plans and produce solutions against the worst scenario that may arise. The excessive resource need arising in the surge capacity experienced in a pandemic should be evaluated correctly and planning should be done accordingly. The pandemics that caused great losses have shown that one of the biggest resource demands is in physical areas. For this reason, it is necessary to create alternative areas. It is necessary to design underground parking lots of hospitals as underground hospitals and evaluate other closed areas within this scope, and to plan parks and reserve areas in cities for the establishment of field hospitals in case of any disaster. With these plannings, the physical space demands that will arise in response to the surge capacity can be met. 
Table 1. SWOT analysis table for surge capacity during Coronavirus disease-2019 pandemic

SWOT analysis

\section{Strenghts in SWOT analysis}

1. Database infrastructure for viruses.

2. Technological infrastructure that allows data (even if not approved) to be shared quickly.

3. Rapid awareness raising of the society through press and social media.

4. Society's rapid adaptation to the pandemic process.

\section{Opportunities in SWOT analysis}

1. Obtaining new data against new types of viruses.

2. Evaluating alternatives to increase capacity in response to the pandemic.

3. Increasing the number of pandemic treatment areas.

4. Starting to produce new respirators.

5. Public and private sector's manufacturing for the supply of materials such as masks, gowns, gloves.

\section{SWOT Matrix}

\section{Strengths}

\section{SO strategy}

Using the data obtained through the pandemic process, studies can be conducted against new virus types that may emerge in the future. In this way, the diagnosis and treatment time can be shortened and the disease can be intervened quickly.

Alternative projects and additional treatment centers should be opened to increase capacity in response to the pandemic. Designing the underground parking lots of hospitals as underground hospitals in case of a disaster, and evaluating other closed areas within this scope are important; Again, parks and reserve areas in cities should be planned for the establishment of field hospitals in case of any disaster. With these plans, the physical space demands that will arise in response to the surge capacity can be met.

During the pandemic, the most needed materials (such as respirators, masks, gloves, gowns) are produced and the possibility of using them without disruption in healthcare services becomes possible. The production and export of these materials will also contribute to the national economy.

\section{ST strategy}

The rapidity of the communication system nowadays positively affects the duration of treatment in a pandemic that will arise. Quick sharing of information and data makes a significant contribution to finding the treatment. is actively used in the pandemic.

It is also possible to use this communication opportunity in the training of health personnel who will actively work in the pandemic. With the correct use of press and social media, among these communication methods, the society can be made aware of the individual protection of people against the virus.

\section{Weaknesses in SWOT analysis}

1. Unknown components of the virus

2. Inability to identify the sourse of the virus rapidly

3. Fast spreading capacity of the virus.

4. Despite the spreading speed, insufficient number of beds.

5. Insufficient number of health personnel compared to the number of patients.

6. Insufficient drugs used in the therapy process.

7. The society's insensitivity to protection methods from the virus.

8. The absence of any vaccine against the virus.

\section{Threats in SWOT analysis}

1. The long duration of finding the vaccine that will be effective against the virus.

2. Insufficient number of trained health personnel to take part in combating pandemic.

3. Lack of adequate hospitalization area for the patients.

4. Depletion of drugs used in the treatment process.

5. Inadequate respiratory equipment used in treatment.

6. Difficulties in supplying materials such as masks, gowns, gloves.

7. Not raising the right awareness of the public during the pandemic process.

\section{Weaknesses}

\section{WO strategy}

Today, the communication infrastructure strong enough to provide information flow allows data and information about emerging diseases to be shared quickly. In this way, the information that can be used in the treatment process reaches the places that need to be reached quickly and contributes positively to the treatment period. In response to the spread of the virus, the capacities of health centers may not be sufficient. In this case, preparation should be made for the worst possible disasters and new projects should be produced to increase capacity. The number of existing health personnel can be considered to be planned and sufficient in response to predictable disaster situations. However, alternative planning can be made in case of unforeseen situations. For example; Health personnel working in different branches can also receive the necessary training in case of an extraordinary disaster and can take part as an additional health team in case of unforeseen situations. Care should be taken to stocking and following drugs that can be used in the treatment process. The drugs that may be needed most urgently should be determined and stock planning should be made according to the risks. In order to increase the knowledge and awareness of the society, planning should be made not only in the pandemic time but also in the normal process. Training programs should be prepared and included in our education system for all extraordinary disasters that may occur.

\section{WT strategy}

In order to reduce the spreading rate of the viruses that may arise, the society must first be informed correctly and in time. Trainings that will raise awareness can be given in for these risks in daily life. These trainings can be done not only in pandemic time but also in the usual time period for preparation and planning. In this way, the awareness of the society can be increased and it can be made more sensitive in case of disaster. 
Table 2. SWOT Matrix table of surge capacity during the Coronavirus disease-2019 pandemic process

Surge Response Capacity

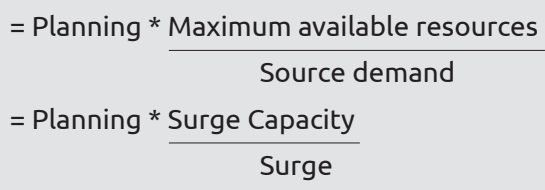

Peer-review: Externally and internally peer-reviewed.

\section{Authorship Contributions}

Concept: M.N.K., Ö.E., Design: M.N.K., Ö.E., Data Collection or Processing: M.N.K., Ö.E., Analysis or Interpretation: M.N.K., Ö.E., Literature Search: M.N.K., Ö.E., Writing: M.N.K., Ö.E.

Conflict of Interest: No conflict of interest was declared by the authors.

Financial Disclosure: The authors declared that this study received no financial support.

\section{References}

1. Davis D, Poste J, Hicks T, Polk D, Rymer T, Jacoby I. hospital bed surge capacity in the event of a mass-casualty incident. Prehosp Disaster Med 2005;20:169-76.

2. Jr Burkle FM. Mass casualty management of a large-scale bioterrorist event: An epidemiological approach that shapes triage decisions. Emerg Med Clin North Am 2002;20:409-36.

3. Hick JL, Hanfling D, Burstein JL, DeAtley C, Barbisch D, Bogdan GM, et al. Health care facility and community strategies for patient care surge capacity. Ann Emerg Med 2004;44:253-61.

4. Adams L. Exploring the concept of surge capacity. OJIN 2009;14:18.

5. Sheikhbardsiri H, Raeisi AR, Nekoei-Moghadam M, Rezaei F. Surge capacity of hospitals in emergencies and disasters with a preparedness approach: a systematic review. Disaster Med Public Health Prep 2017;11:612-20.

6. Traub M, Bradt DA, Joseph AP. The Surge Capacity for People in Emergencies (SCOPE) study in Australasian hospitals. Med JAust 2007;186:394-8.

7. Rathnayake, D., Clarke, M. ve Jayasooriya, L. Hospital surge capacity: The importance of better hospital pre-planning to cope with patient surge during dengue epidemics-A systematic review. Int J Health Manag 2009:1-8.

8. Mills A, Helm J Wang Y. Surge Capacity Deployment In Hospitals: Effectiveness Of Response And Mitigation Strategies. Kelley School of Business Research Paper 17-35.

9. Kelen GD, McCarthy M L. The science of surge. Acad Emerg Med 2006;13:1089-94.
10. Jamil J, Zuabi S, Subbarao I. Disaster metrics quantitative benchmarking of hospital surge capacity trauma-related multiple casualty events. Disaster Med Public Health Prep 2011;5:117-24.

11. Mills A, Helm J, Wang Yu. (2017). Surge Capacity Deployment In Hospitals: Effectiveness Of Response And Mitigation Strategies. SSRN Electronic J 2017:1-32.

12. WHO. WHO Pandemic Influenza Preparedness And Response. Switzerland; 2010.

13. Morens DM, Folkers GK, Fauci AS. What is a pandemic? J Infect Dis 2009;200:1018-21.

14. Lina B. Paleomicrobiology-Past Human Infections. In; Rault D, Drancourt M, editors. Berlin:Springer; 2008.p.199-211.

15. Tognotti E. Influenza pandemics: a historical retrospect. J Infect Dev Ctries 2009;3:331-4.

16. Taubenberger JK, Morens DM. 1918 Influenza: the mother of all pandemics. Emerg Infect Dis 2006;12:15-22.

17. Canadian Pandemic Influenza Plan. (2004). Available from: http:// www.phac-aspc.gc.ca/cpip-pclcpi/

18. WHO. WHO Pandemic Influenza Risk Management. 2017. Available from: https:/www.who.int/influenza/preparedness/ pandemic/influenza_risk_management_update2017/en/

19. Kumar D, Malviya R, Sharma P. Corona virus: A review of COVID-19. EJMO 2020;4:8-25.

20. Guo YR, Cao QD, Hong ZS, Tan YY, Chen SD, Jin HJ, et al. The origin, transmission and clinical therapies on coronavirus disease 2019 (COVID-19) outbreak - an update on the status. Mil Med Res 2020;7:11.

21. Karakoç Y. New Corona Virus (COVID-19) Latest Status and Information Note. (2020). Public Health Professionals Association. Last Accessed Date: 01.04.2020. Available from: https://hasuder.org. tr/yeni-corona-virus-covid-19-son-durum-ve-bilgi-notu/

22. TYBD. Management Of Critical Patients Infected With Covid-19 And Management Of Covid 19 Critical Patients. Türk Yoğun Bakım Derneği; 2020.

23. Connolly MA, Gayer M, Ryan MJ, Salama P, Spiegel P, Heymann DL. Communicable diseases in complex emergencies: impact and challenges. The Lancet 2004;364:1974-83.

24. Mazowita, G. role for primary care. Can Fam Physician 2006;52:951. 
25. Hogg W, Lemelin J, Huston P, Dahrouge H. Increasing epidemic surge capacity with home-based hospitalcare. Can Fam Physician 2006;52:563-4.

26. Izmirlieva M. COVID-19 Pandemic: health system surge capacity. Last Accessed Date: 20.03.2020. Available from: https://ihsmarkit. $\mathrm{com} /$ research-analysis/covid19-pandemic-health-system-surgecapacity.html

27. WHO. Operational Considerations For Case Management Of COVID-19 In Health Facility And Community. 2020. Available from: https://apps.who.int/iris/handle/10665/331492

28. Helman A, Helman R, Kollek D. ED Surge Capacity Strategies in the COVID-19 Pandemic. Last Accessed Date: 01.04.2020. Available from: https://emergencymedicinecases.com/surge-capacitystrategies-covid-19/
29. Green, K. Bello Announces 4-Part Surge Capacity Plan For Local hospitals COVID-19 Efforts. Last Accessed Date: 30.03.2020. Available from: https://www.rochesterfirst.com/coronavirus/watchlive-bello-to-announce-surge-capacity-plan-for-local-hospitals-covid19-efforts/

30. ILO. (2020). Social protection measures against the COVID-19 crisis in the world. ILO Social Protection Monitoring System. Available from: https://www.ilo.org/ankara/publications/WCMS_741444/ lang--tr/index.htm

31. Covid-19'a Yönelik Kamu, Kurum ve Kuruluşların Alacağ Önlemler. (2020). T.C. Sağlık Bakanlığı. Last Accessed Date: 30.04.2020. Available from: https://covid19bilgi.saglik.gov.tr/tr/diger-kamukurumlari 